\title{
Propagation of Quercus cerris, $Q$. petraea, and $Q$. pubescens Seedlings by Stem Cuttings
}

\author{
Daniel Struve ${ }^{3}$ \\ Department of Horticulture and Crop Science, The Ohio State University, \\ 2001 Fyffe Court, Columbus, OH 43210
}

Francesco Ferrini ${ }^{1}$, Chandra Bellasio ${ }^{2}$, and Alessio Fini ${ }^{2}$
Università degli Studi di Firenze, Dipartimento di Scienze della Produzioni
Vegetali, del Suolo e dell' Ambiente Agroforestale, Firenze, Italy

Additional index words. Turkey oak, Sessile Oak, Durmast Oak, Downy Oak, asexual propagation, water use, height-adjusted water use, softwood cuttings

\begin{abstract}
Quercus populations are noted for their genetic variability. However, this variability is difficult to manage through sexual propagation. The purpose of this study was to characterize the early height growth and water use of seedlings from six sources of Quercus native to Italy and to explore the rooting potential of semihardwood stem cuttings taken from young stock plants. There was great variability within a seed source for seedling height (a 1.5- to 7.8-fold difference depending on source) and water use seedling/ day (a 0.7- to 16.5-fold difference). Stem cuttings rooted in high percentages (greater than $\mathbf{7 4 \%}$ ) for two sources of $Q$. petraea (Mattusch) Liebl. and $Q$. pubescens Willd. and one source of $Q$. cerris $\mathrm{L}$. A second $Q$. cerris source had $48 \%$ rooting. $Q$. petraea and $Q$ pubescens cuttings were rooted successfully in mid-June and early August with high survival percentages. Overwinter survival of cuttings from all propagation dates was $96 \%$ (303 of 314 rooted cuttings). In general, seedling stock plant height and water use were not significantly correlated with percent rooting suggesting that those characteristics could be selected independently resulting in tall or short clones with a range of water use efficiencies. Additional testing is needed to determine the relationship between the traits measured on young seedlings and those traits in older individuals.
\end{abstract}

Quercus species are widely distributed and a significant component of forests in the Northern Hemisphere (Johnson et al., 2002). Quercus species are considered droughtresistant (Abrams 1990) with individual species adapted to a range of soil types, including droughty, basic soils (Burns and Honkala, 1990). Species within the Quercus genus are outcrossing and are noted for their heterogeneity (Petit et al., 2002). In red oak (Quercus rubra L.), some economically important traits are under genetic control (Struve and McKeand, 1994). Thus, the Quercus genus is a candidate for genetic improvement. However, the heterogeneity associated with outcrossing makes capturing the genetic variation problematic through sexual propagation.

Successful oak stem cutting propagation protocols use softwood and semihardwood stem cuttings collected from juvenile stock plants, basal dips in relatively high indole butyric acid (IBA) concentrations in combination with various stock plant manipulations (Amissah et al., 2008; Ferrini and Bassuk, 2002). To be commercially successful, an oak

Received for publication 7 July 2010. Accepted for publication 19 Aug. 2010.

${ }^{1}$ Professor.

${ }^{2}$ Graduate Student.

${ }^{3}$ To whom reprint requests should be addressed; e-mail struve.1@osu.edu. propagation system would have both high rooting and overwintering percentages and include quality factors such as root distribution about the base of the cutting (Wilson and Struve, 2004, 2006). Thus, the commercial yield (the percentage of cuttings with a uniform root system and high overwinter survival after propagation) is typically lower than the percentage of cuttings that rooted. Despite the challenges, a few oak clones are commercially propagated by stem cuttings (Head, 1999; Reeves, 2002).

It would be desirable to propagate older genotypes, because time has proven the phenotype, even if only in one environment. Unfortunately, mature stock plants yield cuttings with low rooting potential (Fishel et al., 2003; Zaczek and Steiner, 1997; Zaczek et al., 2006) and plant rejuvenation treatments have met with limited success (Eshed et al., 1996; Griffin and Bassuk, 1996). An alternative to propagating proven but physiological mature genotypes would be to screen physiologically juvenile seedlings for important traits, arresting onset of physiological maturity by hedging, while conducting long-term validation trials.

A previous study with three Italian oak species $[Q$. cerris L., Q. petraea (Mattusch) Liebl., and $Q$. pubesceens Willd.] found significant variation in height and water use among the six sources studied (Struve et al., 2009). The purpose of this experiment was threefold: to characterize the early height growth and water use of seedlings from six sources of Quercus native to Italy; to explore the rooting potential of semihardwood stem cuttings taken from these stock plants; and to determine if early height growth or water use characteristics are correlated with rooting potential.

\section{Materials and Methods}

Acorns were collected from six "veteran" trees. A veteran tree is a tree that, because of its great age, size, or condition is of exceptional cultural, landscape, or nature conservation value (http://en.wikipedia.org/wiki/ Veteran_tree). Acorns were collected from two individuals from each of three species, $Q$. cerris, Q. petraea, and Q. pubesceens, in Fall 2008. Germinated acorns were potted into round black plastic pots $[15 \times 15 \mathrm{~cm}$ using a peatmoss:perlite $(3: 1$ by vol.) substrate]. The substrate was supplemented only with $3 \mathrm{~kg} \cdot \mathrm{m}^{-3}$ of $18 \mathrm{~N}-2.5 \mathrm{P}-7.2 \mathrm{~K}$ 8- to 9-month Osmocote fertilizer (Scotts, Marysville, $\mathrm{OH}$ ). The seedlings were raised outdoors under $60 \%$ shade provided by black shadecloth (Agriombra, Arrigoni, Uggiate Trevano, CO, Italy).

On 17 June, the seedlings were moved to a greenhouse under $50 \%$ shade. Environmental controls were set at $28 / 18{ }^{\circ} \mathrm{C}$ day/night temperature. The seedlings were watered to avoid moisture stress until 19 June. To calculate individual seedling water use, irrigation was withheld between 19 and 23 June. One $\mathrm{h}$ after the 19 June watering, all the individual seedlings were weighed. The seedlings were weighed again on 23 June. The difference in weight was attributed to evapotranspiration and considered as seedling water use. The water use per hour was calculated by dividing total water use by the elapsed time between weighings. Individual seedling heights were also measured on 23 June. Water use was expressed as either water use per seedling ( $\mathrm{g} /$ seedling) or as height-adjusted water use ( $\mathrm{g} / \mathrm{cm}$ seedling height).

On 24 June, cuttings were taken from the each seedling by severing the shoot within $0.5 \mathrm{~cm}$ of the substrate surface. One to five cuttings per seedling were made depending on seedling height. Cutting lengths ranged from 3 to $10 \mathrm{~cm}$ consisting of three to seven nodes. Cutting diameters ranged from 1 to $2 \mathrm{~mm}$. The basal leaves were removed and all remaining leaves were cut in half before the cuttings received 5-s basal $(1 \mathrm{~cm})$ dips first in $0.1 \mathrm{M}$ ascorbic acid and then in $500 \mathrm{ppm}$ solution of the potassium salt of IBA (United States Biochemicals, Cleveland, $\mathrm{OH}$ ). A basal dip in $0.1 \mathrm{M}$ ascorbic acid has been used successfully to root Stewartia pseudocamellia (Maxim.) and Quercus rubra (L.) stem cuttings at high percentages with relatively low auxin concentrations (Blake and Struve, 2008; Struve and Lagrimini, 1999). The cutting collection procedure was modified for the next two propagation events because some stock plants did not regrow after the initial cutting collection. Thus, for the two following propagation events, cuttings were not taken unless there were at least six nodes on the stock plant's shoot. All 
Table 1. The number of seedlings per source for six Quercus sources at various stages during the experiment.

\begin{tabular}{llccccc}
\hline & & \multicolumn{3}{c}{ No. of seedlings used for } & \\
\cline { 3 - 5 } Species & & \multicolumn{3}{c}{ Propagation in } & Alive in \\
\cline { 3 - 5 } Q. cerris & Source & Water use & June & July & August & December \\
\cline { 3 - 6 } Q. petraea & Camaldoli & 45 & 45 & 0 & 0 & 44 \\
& Fiori & 44 & 33 & 0 & 0 & 25 \\
& Baccardi & 45 & 45 & 29 & 38 & 37 \\
& Caiano & 29 & 28 & 0 & 15 & 27 \\
& Camaldoli & 48 & 44 & 20 & 22 & 42 \\
& PDP & 46 & 42 & 26 & 28 & 44 \\
\hline
\end{tabular}

Table 2. Rooting percentage of semihardwood cuttings collected from three species and six sources of Quercus and the percentage of rooted cuttings that broke bud after propagation in June.

\begin{tabular}{llcccccc}
\hline & & & \multicolumn{2}{c}{ Water use } & & \multicolumn{2}{c}{} \\
\cline { 5 - 7 } Species & Source & $\begin{array}{c}\text { Stock plant } \\
\text { ht }(\mathrm{cm})\end{array}$ & $\begin{array}{c}\text { Seedling } \\
\left(\mathrm{g} \cdot \mathrm{h}^{-1}\right)\end{array}$ & $\begin{array}{c}\text { Ht-adjusted } \\
\left(\mathrm{g} \cdot \mathrm{cm}^{-1}\right)\end{array}$ & $\begin{array}{c}\text { Number of } \\
\text { cuttings }\end{array}$ & Rooting & Budbreak \\
\hline Q. cerris & Camaldoli & $13.4 \mathrm{~A}^{\mathbf{z}}$ & $1.9 \mathrm{~A}$ & $0.15 \mathrm{AB}$ & 58 & $48 \mathrm{~A}$ & $82 \mathrm{~A}$ \\
& Fiori & $13.7 \mathrm{~A}$ & $2.3 \mathrm{~B}$ & $0.18 \mathrm{BC}$ & 73 & $81 \mathrm{~B}$ & $73 \mathrm{~A}$ \\
Q. petraea & Baccardi & $23.6 \mathrm{~B}$ & $2.4 \mathrm{~B}$ & $0.11 \mathrm{~A}$ & 104 & $74 \mathrm{~B}$ & $90 \mathrm{~A}$ \\
& Caiano & $20.8 \mathrm{~B}$ & $2.1 \mathrm{AB}$ & $0.12 \mathrm{~A}$ & 58 & $97 \mathrm{~B}$ & $89 \mathrm{~A}$ \\
Q. pubescens & Camaldoli & $9.3 \mathrm{~A}$ & $1.8 \mathrm{~A}$ & $0.20 \mathrm{BC}$ & 53 & $83 \mathrm{~B}$ & $96 \mathrm{~A}$ \\
& PDP & $12.2 \mathrm{~A}$ & $2.3 \mathrm{~B}$ & $0.22 \mathrm{C}$ & 57 & $79 \mathrm{~B}$ & $86 \mathrm{~A}$ \\
\hline
\end{tabular}

${ }^{\mathrm{z}}$ Means within a column followed by different numbers are significantly different from each other at the $\alpha=0.05$ level of significance using the Waller-Duncan mean separation test. cuttings had at least three nodes, leaving the stock plants' shoots with three nodes. This procedure eliminated subsequent stock plant mortality for all but one stock plant.

The propagation substrate was 5015 Root Cubes, an expanded foam product (SmithersOasis, Cuyahoga Fall, OH). Two sheets (each $3.7 \mathrm{~cm}$ high) were placed in plastic flats $[8 \times$ $35 \times 54 \mathrm{~cm}(\mathrm{ht} \times$ length $\times$ width $)]$. Cuttings were placed one per cell $(3.7 \mathrm{~cm}$ on center). The flats were placed in a clear plasticcovered propagation tent within the greenhouse. The mist was set to run $10 \mathrm{~s}$ every 10 min from dawn to dusk, which maintained near $100 \%$ relative humidity. Ambient minimum and maximum temperatures inside the propagation tent were $23 \pm 2{ }^{\circ} \mathrm{C}$ night and $32 \pm 2{ }^{\circ} \mathrm{C}$ day with a $48 \%$ reduction in light.

Cuttings from each source were propagated in a randomized complete block design in which individual cuttings from a seedling within a source were randomly assigned to one of two replications. All the cuttings from an individual stock plant were placed in the same replication. Cuttings were collected at two additional times, 17 July and 3 Aug.,

\section{Q. cerris Camaldoli}
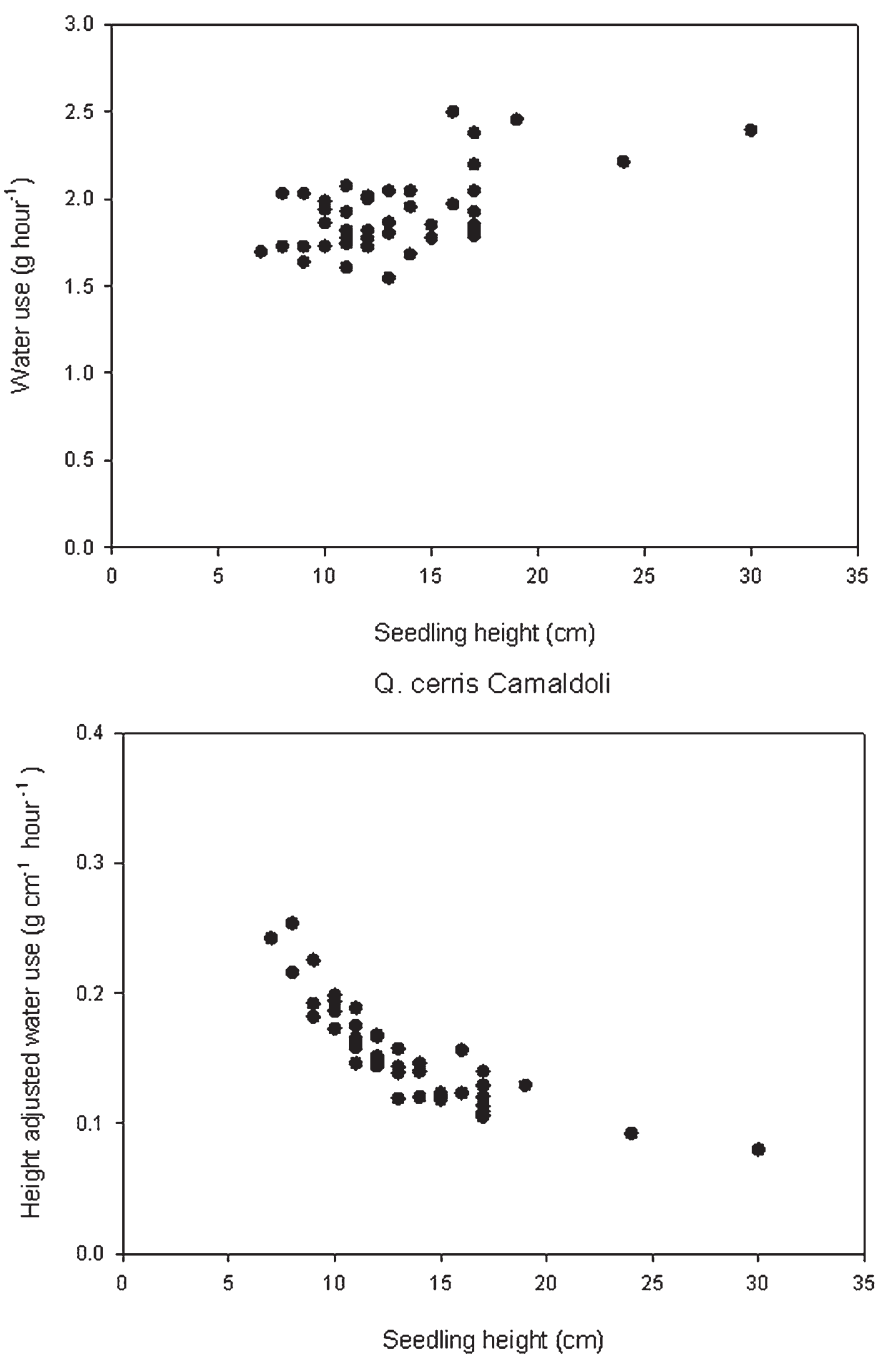

Q. cerris Fiori
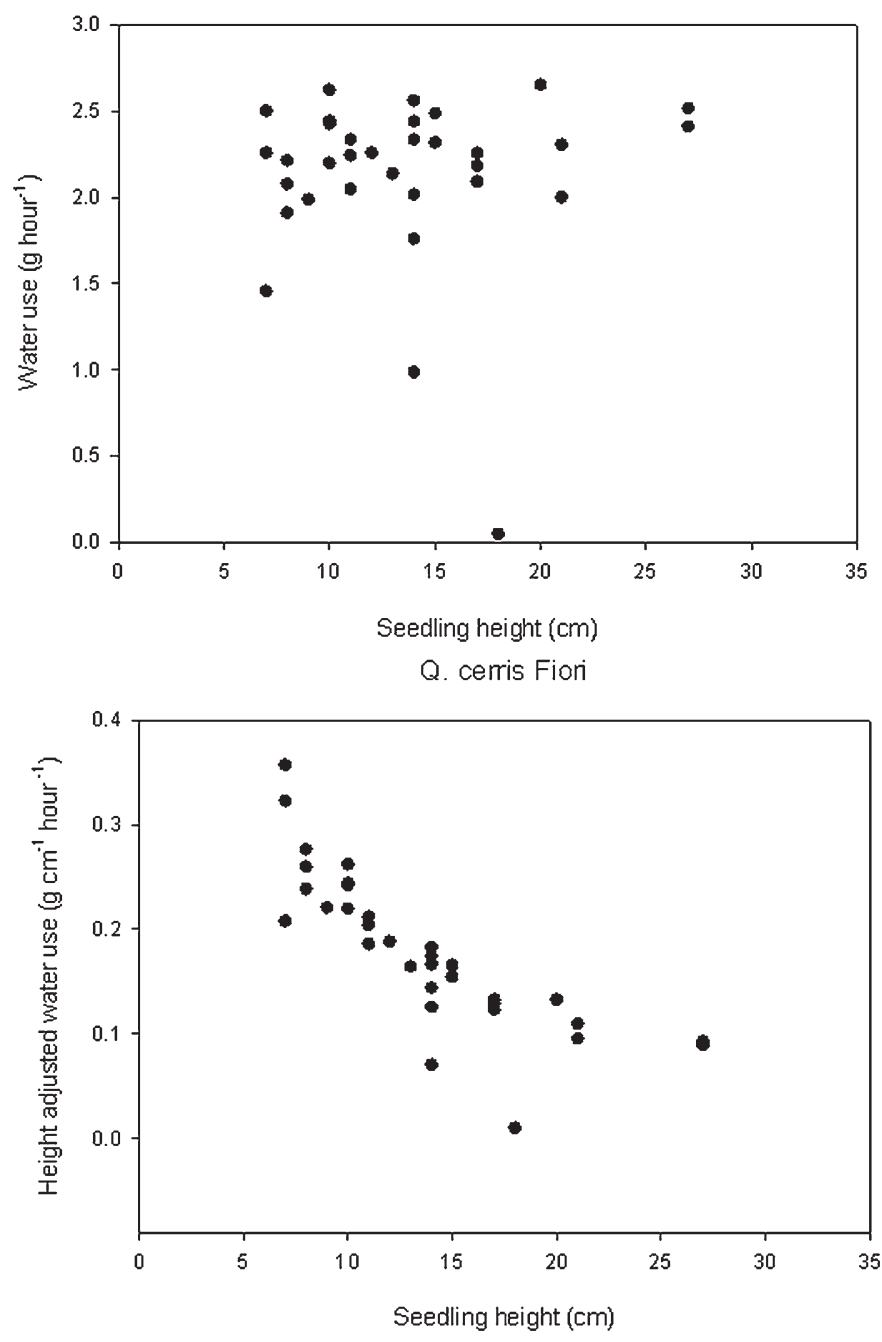

Fig. 1. Individual seedling water use (g water/h) and height-adjusted water use (g water/cm height/h) for two sources of Quercus cerris. 
from stock plants with one or more shoots at least $5 \mathrm{~cm}$ long with six or more nodes. For the July propagation date, only cuttings from one source were propagated. In August, stem cuttings from four sources were propagated.

All cuttings were evaluated for rooting response in Dec. 2009 and overwinter survival was determined in Mar. 2010. A cutting was considered rooted if there was at least one root $1 \mathrm{~cm}$ long. The number of alive but unrooted cuttings was counted in December. Also, the number of cuttings producing at least $1 \mathrm{~cm}$ of new shoot growth after sticking was counted. The number of roots per cutting was counted for only cuttings in the June propagation date.

Rooting percentages for each propagation date and stock plant were calculated and transformed using the arcsine square root transformation before being subjected to analysis of variance (ANOVA) (Version 13.0; SPSS, Chicago, IL). When analyzing for the effect of propagation time on percent rooting, only cuttings from stock plants common to the propagation times being analyzed were used in the analysis. The untransformed mean rooting percentages are reported in the tables. The ANOVA used a fixed-effects model with seed source as the main effect. Means were declared significantly different using the Waller-Duncan test of significance at the $\alpha=0.05$ level of significance (Version 17.0; SPSS). Correlation coefficients were calculated using the correlation procedure within SPSS (Version 17.0).

\section{Results and Discussion}

There were between 28 and 45 seedlings per source in the June water use characterization (Table 1). There were fewer seedlings used as stock plants for the June propagation because some of the stock plants were too small to yield at least one cutting. The $Q$. cerris sources had relatively slow shoot growth and were slower to regenerate shoots after cutting collection; thus, $Q$. cerris cuttings were collected only in June. Both $Q$. petraea and $Q$. pubescens sources had sufficient regrowth to provide cuttings for June and August propagation dates. Only 29 of the 45 seedlings of the $Q$. petraea Baccardi source had regrown sufficiently to provide cuttings at three propagation dates. For two sources, stock plant mortality was high, $43 \%$ and $18 \%$ for $Q$. cerris Fiori and $Q$ petraea Caiano, respectively (Table 2 ).

Average seedling height in June varied among the six sources from 9.3 to $23.6 \mathrm{~cm}$
(Table 2; Figs. 1, 2, and 3). Seedlings from both $Q$. petraea sources were taller than the other four sources (Table 2). There was nearly a twofold difference in height among seedlings within a source. The minimum range in height was 6 to $15 \mathrm{~cm}$ in $Q$. cerris Camaldoli seedlings and the maximum range was 6 to $53 \mathrm{~cm}$ for $Q$. pubescens PDP.

Average seedling water use ( $\mathrm{g}$ seedling $/ \mathrm{h}$ ) was least for $Q$. cerris and $Q$. pubescens Camaldoli sources (Table 2). Individual seedling water use within a source ranged from 1.5 to 2.5 (Q. cerris Camaldoli) to 0.2 to $3.5 \mathrm{~g} / \mathrm{plant} / \mathrm{h}(Q$. petraea Baccardi; Figs. 1 and 2). Height-adjusted water use $\left(\mathrm{g} \cdot \mathrm{cm}^{-1} /\right.$ height $/ \mathrm{h}$ ) was lowest in the two $Q$. petraea sources; it was nearly half that of the $Q$. pubescens sources (Table 2). The variation in height-adjusted water use within sources was less than that for seedling water use; it ranged from 0.02 to 0.20 (Q. petraea Baccardi) to 0.04 to $0.95 \mathrm{~g} \cdot \mathrm{cm}^{-1} /$ height $/ \mathrm{h}(Q$. pubescens PDP; Fig. 1 versus Fig. 3).

In general, taller seedlings used more water per hour than shorter seedlings. However, the two $Q$. cerris sources had similar height but significantly different water use per seedling, as did the two $Q$. pubescens sources. There was
Q. petraea Baccardi
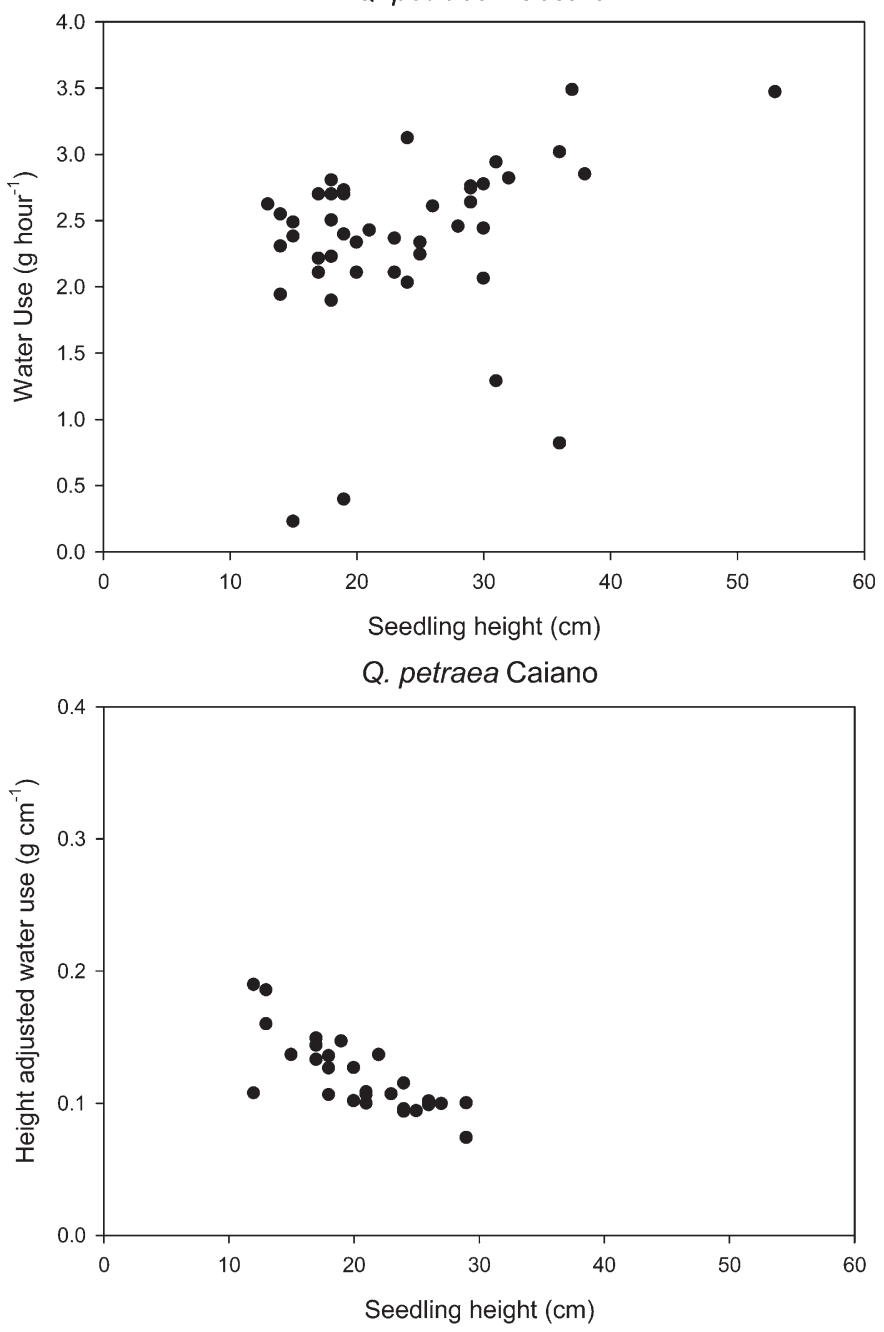

Q. petraea Caiano
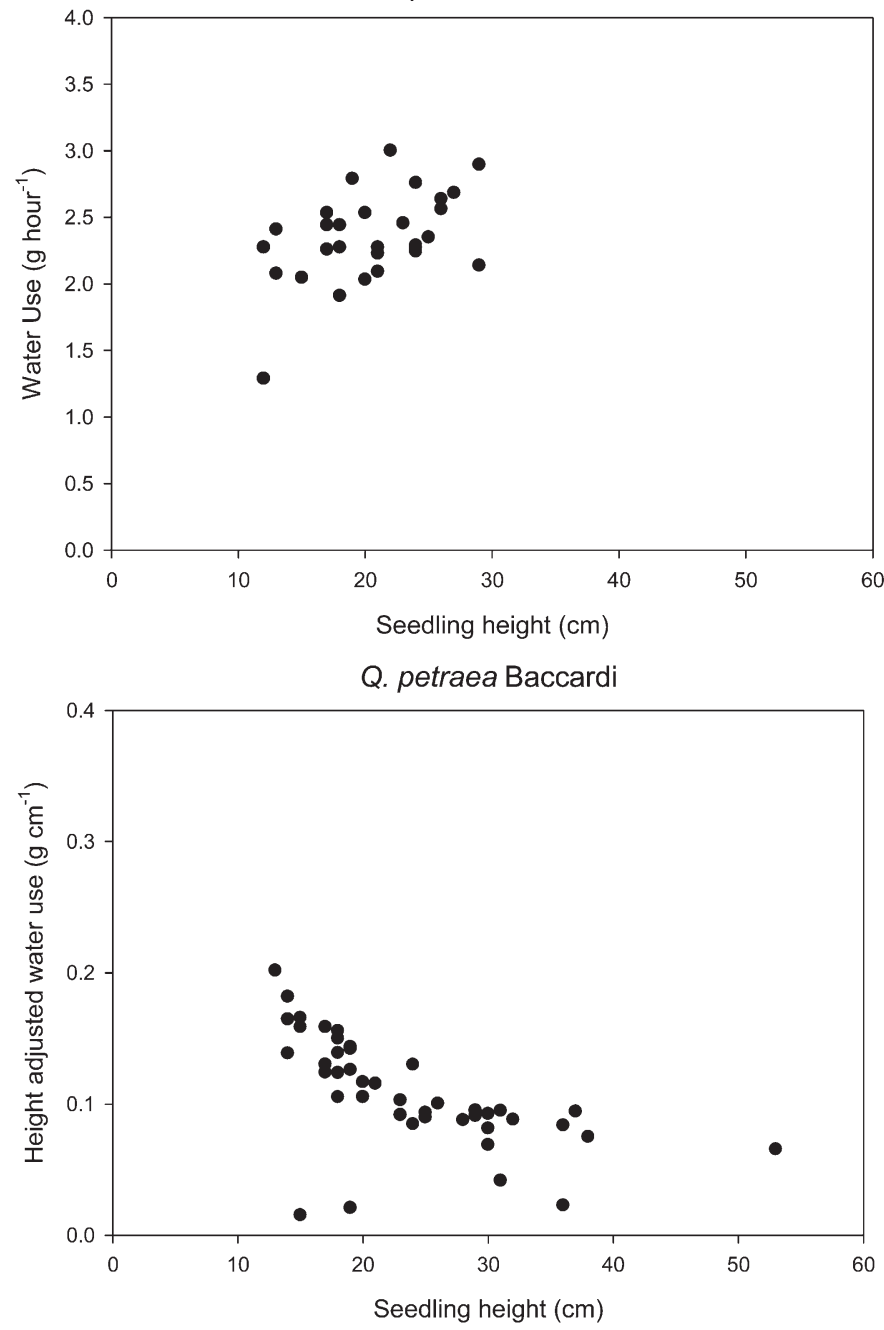

Fig. 2. Individual seedling water use (g water/h) and height-adjusted water use (g water/cm height/h) for two sources of Quercus petraea. 

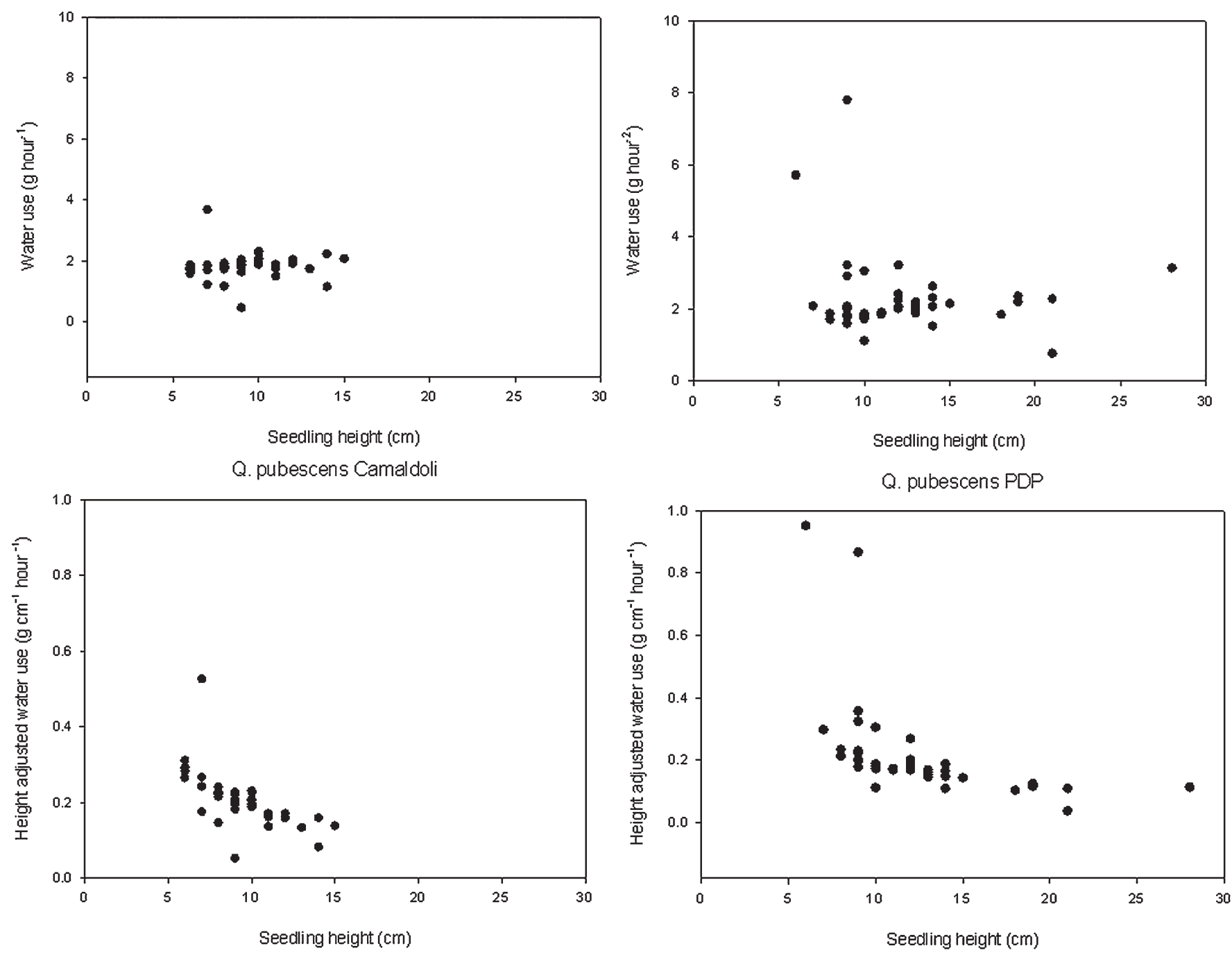

Fig. 3. Individual seedling water use $(\mathrm{g}$ water/h) and height-adjusted water use $(\mathrm{g}$ water/cm height/h) for two sources of Quercus pubescens.

no difference in height or water use between the $Q$. petraea sources. With regard to the height-adjusted water use, the tallest seedlings (Q. petraea sources) had the lowest and the shortest seedlings ( $Q$. pubescens sources) had the highest height-adjusted water use. Heightadjusted water use was used as a possible selection statistic for practical reasons.

A nursery manager sells tree whips by height. Thus, selecting within an even aged cohort for tall seedlings with low heightadjusted water use would reduce production times and water use per production cycle. Height-adjusted water use is similar to nitrogen $(\mathrm{N})$ productivity [with units of dry weight increase per unit $\mathrm{N}$ per unit time in contrast with $\mathrm{N}$ efficiency with units of dry weight increase per unit N (Ingestad, 1979)]. There were also seedlings with high height-adjusted water use, which would require more time and/or water to produce whips of a given height than if seedlings with low heightadjusted water use were used. Thus, it was important to determine the linkage between height-adjusted water use and propagation success.
The rooting response for stem cuttings taken in June and evaluated in December exceeded $74 \%$ for all sources except $Q$. cerris Camaldoli in which it was $48 \%$ (Table 2). Root regeneration was rapid; some individual cuttings had roots emerging from the rooting cubes within $11 \mathrm{~d}$ of sticking. The number of roots per cutting averaged three for most cuttings except for those of the $Q$. cerris Camaldoli source, in which there was one root per cutting. For all the sources, at least $73 \%$ of the rooted cuttings broke bud between propagation and Dec. 2009. The cuttings that rooted but did not break bud after rooting were also alive in December. For these sources, breaking bud after rooting does not seem to be a requirement for survival into early winter. Unrooted cuttings were alive in December; thus, the rooting percentage was unaffected by cuttings rotting before rooting, and the June rooting percentage is a true measure of the rooting potential of these semihardwood stem cuttings (Wilson and Struve, 2004). Except for cuttings from the $Q$. cerris Camaldoli source (which averaged one root per cutting), the commercially acceptable propagation success rate was approximated by the rooting percentage because cuttings averaged three roots per cutting and death of rooted cuttings was negligible through Mar. 2010. The Mar. 2010 overwintering survival of rooted cuttings averaged over all propagation dates was $96 \%$ (303 of 314 rooted cuttings).

Other than the percent of cuttings that broke bud after rooting (which was significantly and positively correlated with percent rooting), there were few significant correlations between rooting percentage and seedling height, water use, or height-adjusted water use (Table 3 ). In the Q. cerris Camaldoli source, cuttings from taller stock plants tended to root in higher percentages than those collected from shorter stock plants ( $r=$ $0.509)$ and height-adjusted water use was negatively correlated with percent rooting $(r=$ -0.378 ). Stock plant height was negatively correlated with percent rooting in stem cuttings of the $Q$. petraea Caiano source ( $r=$ -0.406). Other than these exceptions, early seedling height and water use characteristics were not significantly correlated with percent rooting of these semihardwood stem cuttings. 
Table 3. Correlations between percent rooting and June height, hourly seedling water use (HSWU), heightadjusted water use (HAWU), and percent of rooted cuttings breaking bud (BB) after the June propagation data for six Quercus sources.

\begin{tabular}{|c|c|c|c|c|c|c|}
\hline \multirow[b]{3}{*}{ Parameter } & \multicolumn{6}{|c|}{ Species and source } \\
\hline & \multicolumn{2}{|c|}{ Q. cerris } & \multicolumn{2}{|c|}{ Q. petraea } & \multicolumn{2}{|c|}{ Q. pubescens } \\
\hline & Camaldoli & Fiori & Baccardi & $\overline{\text { Caiano }}$ & $\overline{\text { Camaldoli }}$ & $\overline{\mathrm{PDP}}$ \\
\hline Height & $0.590^{z}$ & 0.288 & 0.097 & -0.406 & 0.081 & 0.064 \\
\hline HSWUw & 0.330 & -0.231 & -0.105 & -0.213 & 0.055 & 0.119 \\
\hline HAWU ${ }^{x}$ & -0.378 & -0.318 & -0.187 & 0.268 & -0.076 & 0.081 \\
\hline $\mathrm{BB}^{\mathrm{y}}$ & 0.801 & 0.560 & 0.680 & 0.664 & 0.540 & 0.589 \\
\hline
\end{tabular}

${ }^{\mathrm{z}}$ Means in bold are significant at $\alpha=0.05$ level.

yPercent of rooted cuttings in the June propagation date that broke bud after rooting.

${ }^{x}$ Height adjustment was calculated as the quotient of the average 3-d water use per seedling and seedling height.

${ }^{\text {w}}$ Average water use per seedling per hour over a 3-d period.

Table 4. Percent rooting of semihardwood cuttings from four sources of Quercus at two propagation dates. ${ }^{2}$

\begin{tabular}{|c|c|c|c|c|c|c|}
\hline \multirow[b]{3}{*}{ Species } & \multirow[b]{3}{*}{ Source } & \multicolumn{3}{|c|}{ Number of } & \multirow{2}{*}{\multicolumn{2}{|c|}{ Propagation date (rooting \%) }} \\
\hline & & \multirow[b]{2}{*}{ Stock plants } & \multicolumn{2}{|c|}{ Cuttings } & & \\
\hline & & & June & August & June & August \\
\hline \multirow[t]{2}{*}{ Q. petraea } & Baccardi & 29 & 63 & 43 & $72 \mathrm{~A}^{\mathrm{x}}$ & $100 \mathrm{~A}$ \\
\hline & Caiano & 15 & 29 & 17 & $96 \mathrm{~A}$ & $100 \mathrm{~A}$ \\
\hline \multirow[t]{3}{*}{ Q. pubescens } & Camaldoli & 19 & 22 & 37 & $84 \mathrm{~A}$ & $89 \mathrm{~A}$ \\
\hline & PDP & 27 & 35 & 44 & $85 \mathrm{~A}$ & $97 \mathrm{~A}$ \\
\hline & & & & Average & $82 A^{y}$ & $97 \mathrm{~B}$ \\
\hline
\end{tabular}

${ }^{\mathrm{z}}$ Cuttings were collected from the same stock plants at each propagation date.

${ }^{y}$ Means for the average percent rooting for the two propagation dates are significantly different from each other at the $\alpha=0.05$ level of significance using the Waller-Duncan mean separation test.

${ }^{\mathrm{x}}$ Means within a propagation date followed by different numbers are significantly different from each other at the $\alpha=0.05$ level of significance using the Waller-Duncan mean separation test.

Thus, clones could potentially be developed from tall or short seedlings or seedlings with high or low water use.

Sufficient resprouting occurred from both $Q$. petraea and $Q$. pubescens sources to allow two propagation dates between June and August. The number of cuttings per stock plant was higher in June than in August for both $Q$. petraea sources and lower for both $Q$. pubescens sources (Table 4). Averaged over all sources, percent rooting was higher in August than June ( $97 \%$ versus $82 \%$, respectively), but it did not differ within a source between propagation dates except for cuttings of the $Q$. petraea Baccardi source in which it was higher in August (Table 4). Few cuttings propagated in August broke bud between sticking and December, but all rooted cuttings were healthy in December. The relatively late propagation date did not seem to be a factor affecting rooting or cutting survival in these sources.

Stock plants from $Q$. petraea Baccardi were vigorous enough to provide cuttings from three propagation dates: 22 June, 13 July, and 3 Aug. Stem cuttings rooted $72 \%, 100 \%$, and $83 \%$ for the June, July, and August propagation dates, respectively. Rooting was higher in July than in June or August $(P=0.01)$. None of the cuttings that rooted in the August propagation date broke bud after rooting. Few unrooted cutting rotted during propagation.

To the authors' knowledge, this is the first article reporting the successful propagation of these species by stem cuttings. Rooting response was relatively high for these sources when using a relatively low IBA concentration. Also, the propagation window appears to be wide; cuttings from four sources could be rooted between June and August. For most of these sources, there were low correlations among rooting percentage, seedling height growth, and water use characteristics. Thus, clones could be developed from either tall or short stock plants with either high or low water use.

The great variation in height and water use within these sources and the relatively high rooting potential of semihardwood stem cuttings justifies the increased cost of clonal propagation. Potentially, uniform crops of rapidly growing clones with low height-adjusted water use (i.e., high water use productivity) could be grown. Additional tests are being established to determine if the juvenile height and water use traits persist with age.

\section{Literature Cited}

Abrams, M.D. 1990. Adaption and response to drought in Quercus species of North America. Tree Physiol. 7:227-238.

Amissah, J.N., D.J. Paolillo, Jr., and N. Bassuk. 2008. Adventitious root formation in stem cuttings of Quercus bicolor and $Q$. macrocarpa and its relationship to stem anatomy. J. Amer. Soc. Hort. Sci. 133:479-486.

Blake, M.K. and D.K. Struve. 2008. Increasing the rooting potential of Quercus palustris Munchh. and Quercus rubra L. stem cuttings, p. 115-120. In: Watson, G., L. Costello, B. Scharenbroch, and E. Gilman (eds.). The landscape below ground III Int'l Soc. Arboric., Champaign, IL.

Burns, R.M. and B.H. Honkala. 1990. Silvics of North America: Vol. 2. Hardwoods. USDA For. Serv. Agri. Hdb. 654.

Eshed, Y., J. Riov, and N. Atzmon. 1996. Rooting oak cuttings from gibberellins-treated stock plants. HortScience 31:872-873.

Ferrini, F. and N.L. Bassuk. 2002. Propagation techniques of some ornamental oak species (Quercus spp.). Advances in Horticultural Science 16:38-42.

Fishel, D.W., J.J. Zaczek, and J.E. Preece. 2003. Positional influence on rooting of shoots forced from the main bole of swamp white oak and northern red oak. Can. J. For. Res. 33:705711.

Griffin, J. and N. Bassuk. 1996. Preliminary progress on the asexual propagation of oaks. Proc. Int'1. Plant Prop. Soc. 46:487-493.

Head, R.H. 1999. Cutting-grown Quercus: The future. Proc. Int'l. Plant Prop. Soc. 49:514 516.

Ingestad, T. 1979. Nitrogen stress in birch seedlings. II. $\mathrm{N}, \mathrm{K}, \mathrm{P}, \mathrm{Ca}$ and $\mathrm{Mg}$ nutrition. Physiol. Plant. 45:149-157.

Johnson, P.S., S.R. Shifley, and R. Rogers. 2002 The ecology and silviculture of oaks. CABI Publ., New York, NY.

Petit, R.J., U.M. Csaikl, S. Bordacs, K. Burg, E Coart, J. Cottrell, B. Van Dam, J.D. Deans, S. Cumolin-Lapegue, S. Fineschi, R. Finkeldey, A. Gillies, I. Glaz, P.G. Goicoechea, J.S. Jensen, A.O. Konig, A.J. Lowe, S.F. Madsen, G. Matyas, R.C. Munro, M. Olalde, M. Pemonge, F. Popescu, D. Slade, H. Tabbener, D. Taurchini, S.G.M. De Vries, B. Ziegenhagen, and A. Kremer. 2002. Chloroplast DNA variation in European white oak Phylogeography and patterns of diversity based on data from over 2600 populations. For. Ecol. Mgt. 156: $5-26$.

Reeves, B. 2002. Propagation of Quercus virginiana by cuttings. Proc. Int'l. Plant Prop. Soc. 52:448-449.

Struve, D.K., F. Ferrini, A. Fini, and L. Pennati. 2009. Relative growth and water use of seedlings from three Italian Quercus species. Arboricul. \& Urban For. 35:113-121.

Struve, D.K. and M. Lagrimini. 1999. Survival and growth of Stewartia pseudocamellia rooted cuttings and seedlings. J. Environ. Hort. 17:5356.

Struve, D.K. and S.E. McKeand. 1994. Importance of red oak mother tree to nursery productivity. J. Environ. Hort. 12:23-26.

Wilson, P.J. and D.K. Struve. 2004. Overwinter mortality in stem cuttings. J. Hort. Sci. Biotechnol. 79:842-849.

Wilson, P.J. and D.K. Struve. 2006. Axillary shoot growth, rooting and overwinter survival in stem cuttings of Viburnum dentatum 'Chicago Luster'. J. Environ. Hort. 24:6-12.

Zaczek, J.J. and K.C. Steiner. 1997. Graftingmediated meristem selection influences rooting success of Quercus rubra. Can. J. For. Res. 27:86-97.

Zaczek, J.J., K.C. Steiner, C.W. Heuser, Jr., and W.M. Tzilkowski. 2006. Effects of serial grafting, ontogeny, and genotype of Quercus rubra cuttings. Can. J. For. Res. 36:123-131. 